\title{
Multiplex Polymerase Chain Reaction Based Typing of Staphylococcal Chromosomal Cassette mec of Methicillin Resistant Staphylococcus aureus from Selected Hospitals in Lahore
}

\author{
Romeeza $\mathrm{T}^{\mathrm{a}}$, Naeem $\mathrm{R}^{\mathrm{b}}$ and Nadeem $\mathrm{A}^{\mathrm{a}}$ \\ a Department of Immunology, University of Health Sciences Lahore, Pakistan \\ b School of Biological Sciences, University of the Punjab, Lahore, Pakistan
}

\begin{abstract}
Introduction: Staphylococcus aureus is one of the leading causes of nosocomial infections. Prevalence of methicillin resistant Staphylococcus aureus (MRSA) has been reported in up to 42\% of isolates in Pakistan. Methicillin resistance is encoded by the mecA gene and it is transferred by a unique genetic vector called staphylococcal chromosomal cassette (SCCmec). Depending upon the selection pressures of antibiotics, different types of SCCmec elements may prevail in different parts of the world. Materials and Methods: Therefore, this study was designed to find out the major SCCmec types present in selected hospitals of Lahore. For this purpose thirty five MRSA isolates were collected. These strains were reconfirmed and SCCmec types were determined by multiplex PCR. Results: It was found that 21 (60\%) isolates possess SCCmec type IA while 14 (40\%) isolates possess SCCmec type IIC. Conclusion: These cassettes are shown to be multiresistant and have not been reported in other Asian countries so far.
\end{abstract}

KEYWORDS: MRSA, mecA, SCCmec, multiplex PCR

\section{INTRODUCTION}

Staphylococcus aureus is a Gram-positive bacterium that resides in the anterior nasal vestibules and on the skin of about $25 \%$ to $30 \%$ of healthy individuals. ${ }^{1,2}$ It causes various pyogenic, invasive and toxin mediated infections in humans. ${ }^{1,3}$ It possesses various mechanisms to evade defensive immunological mechanisms. ${ }^{4,5}$

Penicillin was used to treat S. aureus infections during the 1940s but due to acquisition of a B-lactamase plasmid, it became resistant to penicillin shortly. ${ }^{6}$ In 1960 methicillin was launched to treat penicillin resistant S. aureus infections but within a year, due to chromosomal integration of mecA gene $(2.1 \mathrm{~kb})$, methicillin resistant $S$. aureus (MRSA) was evolved in England. ${ }^{1,7}$ The mecA gene encodes for penicillin binding protein $2 \mathrm{a}$ (PBP-2a) instead of normal penicillin binding proteins. The active site of PBP-2a blocks binding of all B-lactams but allows transpeptidation of cell wall peptidoglycan and therefore, S. aureus continues to survive. ${ }^{8}$

The mecA gene is present on a mobile genetic ele-

Corresponding author;

Nadeem Afzal

Department of Immunology

University of Health Sciences

Lahore, Pakistan

e-mail: aann30@hotmail.com ment called Staphylococcal Cassette Chromosome $\mathrm{mec}(\mathrm{SCCmec}){ }^{7} \mathrm{SCCmec}$ is a unique class of genetic vectors that is different from plasmids, transposons and bacteriophages. ${ }^{9}$ Molecular weight of SCCmec ranges from $21 \mathrm{~kb}$ to $67 \mathrm{~kb}$. This genetic vector is also present in other staphylococci but not outside this genus. ${ }^{1,10} \mathrm{SCCmec}$ is inserted at a unique site called attBscc, which is near the origin of replication of $S$. aureus chromosome. This insertion occurs at the $3^{\prime}$ end of an open reading frame of unknown function called orfX. ${ }^{6}$

SCCmec element is composed of two essential gene complexes: mec gene complex and ccr gene complex. The mec gene complex carries different antibiotic resistance genes while ccr region encodes enzymes called cassette chromosome recombinases that are involved in excision and integration of the whole mobile genetic element. The rest of the region is called junkyard $(\mathrm{J})$ region. $^{7}$ So far, based on the combination of mec and $\mathrm{ccr}$ genes, seven SCCmec types have been identified. ${ }^{1,11,12}$ Depending upon the genetic heterogeneity, five classes of mec gene complexes (A-E) have been described. Each mec class contains mecA gene, IS431, and regulatory genes (mecl and mecRI). Five allotypes of ccr have been recognized yet. Variants of SCCmec types are classified according to J region. SCCmec type I (except IA), SCCmec type IV (except IV $\mathrm{A}$ and IV c) and $\mathrm{SCCmec}$ type $\mathrm{V}$ are resistant to methicillin only whereas rest of the cassettes are multiresistant due to integration of different plasmids, transposons and insertion sequences. ${ }^{1}$ 
Major types of SCCmec elements present in different Asian countries have been determined such as in Korea (SCCmec type II and SCCmec type IV), Japan (SCCmec type II), China ( SCCmec type III and SCCmec type IIIA), India (SCC mec type III and SCCmec type IIIA), Indonesia (SCCmec type IIIA), Philippines (SCCmec type II, SCCmec type IIIA, and SCCmec type IV) Saudi Arabia (SCCmec type IIIA), Singapore (SCCmec type III, SCCmec type IIIA), Sri Lanka (SCCmec type IIIA), Taiwan (SCCmec type III, SCCmec type IIIA, SCCmec type IV), Thailand (SCCmec type III and SCCmec type IIIA), and in Vietnam (SCCmec type IIIA) ${ }^{13,14}$.

However, SCCmec type prevalent in Pakistan is not known. Therefore the present study was designed to determine major SCCmec type present in isolates from selected hospitals of Lahore.

\section{MATERIALS AND METHODS}

S. aureus isolates: Thirty five isolates of methicillin resistant Staphylococcus aureus were collected by non-probability and convenience sampling technique from various hospitals of Lahore such as Sheikh Zayed Hospital, Ittefaq Hospital, Fatima Memorial Hospital, Shaukut Khanum Hospital, Children Hospital and Chughtai's Laboratory during the period from February to May 2008. These isolates were obtained from pus, blood, sputum and tracheal aspirates. They were reconfirmed as Staphylococcus aureus by Gram staining, mannitol fermentation, coagulase (slide and tube) and DNase production.

Reconfirmation of methicillin resistance: Methicillin resistance was reconfirmed by anti-PBP $2 a$ latex agglutination kit (Oxoid).

Isolation of chromosomal DNA: Cultures were inoculated in brain heart infusion $(\mathrm{BHI})$ broth and incubated in shaking water bath at $37^{\circ} \mathrm{C}$ for 20 to 22 hours. Chromosomal DNA was isolated according to instructions of DNA extraction kit manufacturer (Roboscreen). To check the integrity of eluted DNA, it was mixed with DNA loading buffer (bromophenol blue and sucrose) and loaded on 1\% agarose gel in $1 \mathrm{X}$ TAE (tris acetate EDTA) buffer and electrophoresed at 100 Volts. Gel was stained with ethidium bromide dye and visualized on UV illuminator and Gel Doc System. Samples showing intact band of genomic DNA were included in the study.

Multiplex PCR: The SCCmec types were classified according to the presence or absence of amplicons using SCCmec type specific primers as designed by Oliveria given in Table I.15 Reaction mixture volume was 50 $\mu \mathrm{l}$. The mixture contained DNA (5 ng), dNTPs (10 mM each), $\mathrm{MgCl}_{2}$ (50 mM), Taq Polymerase (5 units/ $\mu \mathrm{l}$ ), Taq buffer (10X), Primers: CIF2 F2 (13.2 nmol), CIF2 R2 $(13.6 \mathrm{nmol}), \mathrm{KDP} F 1(14.3 \mathrm{nmol}), \mathrm{KDP}$ R1 $(11.8 \mathrm{nmol})$, MEC1 P2 (15.2 nmol), MEC1 P3 (16.7 nmol), DCS F2 $(16.1 \mathrm{nmol})$, DCS R1 $(15.0 \mathrm{nmol}), \mathrm{RIF} 4 \mathrm{F3}(14.3 \mathrm{nmol})$, RIF4 R9 (16.3 nmol), RIF5 F10 (14.0 nmol), RIF5 F13
(13.9 $\mathrm{nmol})$, IS431 P4 (16.3 nmol), pUB110 R1 (13.8 nmol), IS431 P4 (16.3 nmol), pT181 R1 (13.2 nmol), MECA P4 (14.0 nmol), MECA P7 (16.2 nmol). Thirty cycles of PCR were performed with the following parameters: predenaturation $\left(4\right.$ minutes at $\left.94^{\circ} \mathrm{C}\right)$, Denaturation (30 seconds at $94^{\circ} \mathrm{C}$ ), annealing (30 seconds at $\left.53^{\circ} \mathrm{C}\right)$, elongation $\left(1\right.$ minute at $\left.72^{\circ} \mathrm{C}\right)$, postextension ( 4 minutes at $72^{\circ} \mathrm{C}$ ). Amplified product was mixed with DNA loading buffer and loaded on $2 \%$ agarose in 1X TAE buffer and electrophoresed at 100 Volts. Gel was stained with ethidium bromide and visualized on UV illuminator and Gel Doc System.

Data analysis: Data was entered and analyzed using Excel 2003. Frequencies and percentages are given for qualitative variables.

\section{RESULTS}

The various isolates of MRSA used in this study were collected from blood $(n=18)$, pus $(n=10)$, sputum $(n=5)$, intra venous line $(n=1)$ and from tracheal aspirate $(n=1)$. SCCmec types found in different hospitals of Lahore are given in Table II. It has been noted that twenty one isolates $(60 \%)$ of MRSA possessed SCCmec type IA (variant of SCCmec type I). It has been shown that SCCmec type I produces two bands of $495 \mathrm{bp}$ and 342 bp. However, SCCmec type IA produces an extra band of 381 bp (Figure 1). SCCmec type IIC (variant of SCCmec type II) was present in 14 isolates (40\%) of MRSA. SCCmec type II produces four bands: $381 \mathrm{bp}$, 342 bp, 284 bp and 209 bp. However, SCCmec type IIC differs from SCCmec type II because it lacks amplimers of 284 bp and 209 bp (Figure 2). Methicillin resistant gene mecA produced an amplicon of $162 \mathrm{bp}$.

Table I. Sequences of primers used for PCR amplification of loci

\begin{tabular}{|c|c|c|c|c|c|}
\hline Locus & Primer & Sequence $\left(5^{\prime}-3^{\prime}\right)$ & Location & $\begin{array}{c}\text { Amplicon } \\
\text { size } \\
\text { (base pairs) }\end{array}$ & Specificity \\
\hline \multirow[t]{2}{*}{ A } & CIF2F2 & ITCGAGTTGCTGATGAAGAAGG & 18398-18419 & \multirow[t]{2}{*}{495} & \multirow[t]{2}{*}{ I } \\
\hline & CIF2 R2 & ATTTACCACAAGGACTACCAGC & $18892-18871$ & & \\
\hline \multirow[t]{2}{*}{ B } & KDPF1 & AATCATCTGCCATTGGTGATGC & $10445-10467$ & \multirow[t]{2}{*}{284} & \multirow[t]{2}{*}{ II } \\
\hline & KDP R1 & CGAATGAAGTGAAAGAAAGTGG & 10728-10707 & & \\
\hline \multirow[t]{2}{*}{ C } & MEC1 P2 & ATCAAGACTTGCATTCAGGC & $42428-42447$ & \multirow[t]{2}{*}{209} & \multirow[t]{2}{*}{ II, III } \\
\hline & MEC1 P3 & GCGGITICAATTCACTTGTC & $42636-42617$ & & \\
\hline \multirow[t]{2}{*}{ D } & DCSF2 & СATCCTATGATAGCTTGGTC & $38011-37992$ & \multirow[t]{2}{*}{342} & \multirow[t]{2}{*}{ I, II, IV } \\
\hline & DCSR1 & CTAAATCATAGCCATGACCG & $37670-37689$ & & \\
\hline \multirow[t]{2}{*}{$\mathrm{E}$} & RIF4F3 & GTGATTGTTCGAGATATGTGG & $45587-45607$ & \multirow[t]{2}{*}{243} & \multirow[t]{2}{*}{ III } \\
\hline & RIF4 R9 & CGCTITATCTGTATCTATCGC & $45829-45809$ & & \\
\hline \multirow[t]{2}{*}{$\mathrm{F}$} & RIF5 F10 & TTCTTAAGTACACGCTGAATCG & 59573-59594 & \multirow[t]{2}{*}{414} & \multirow[t]{2}{*}{ III } \\
\hline & RIF5 F13 & GTCACAGTAATTCCATCAATGC & 59986-59\%5 & & \\
\hline \multirow[t]{2}{*}{ G } & IS431 P4 & CAGGTCTCTTCAGATCTACG & 49963-49982 & \multirow[t]{2}{*}{381} & \multirow[t]{2}{*}{ IA } \\
\hline & pUB110R1 & GAGCCATAAACACCAATAGCC & 50343-50323 & & \\
\hline \multirow[t]{2}{*}{ H } & IS431 P4 & CAGGTCTCTTCAGATCTACG & $29654-29673$ & \multirow[t]{2}{*}{303} & \multirow[t]{2}{*}{ IIIA } \\
\hline & pT181 R1 & GAAGAATGGGGAAAGCTTCAC & 29976-29956 & & \\
\hline $\operatorname{mec} A$ & $\begin{array}{l}\text { MECAP4 } \\
\text { MECAP7 } \\
\end{array}$ & $\begin{array}{l}\text { TCCAGATTACAACTTCACCAGG } \\
\text { CCACTTCATATCTTGTAACG }\end{array}$ & $\begin{array}{l}1190-1211 \\
1351-1332 \\
\end{array}$ & 162 & $\begin{array}{l}\text { Internal } \\
\text { control }\end{array}$ \\
\hline
\end{tabular}


Table II. SCCmec types found in different hospitals of Lahore

\begin{tabular}{|l|c|c|}
\hline \multicolumn{1}{|c|}{ Hospitals } & SCCmec type IA & SCCmec type IIC \\
\hline Sheikh Zayed Hospital $(\mathrm{n}=8)$ & 4 & 4 \\
\hline Ittefaq Hospital $(\mathrm{n}=8)$ & 5 & 3 \\
\hline Fatima Mernorial Hospital $(\mathrm{n}=2)$ & 1 & 1 \\
\hline Shaukut Khanum Hospital $(\mathrm{n}=5)$ & 3 & 2 \\
\hline Children Hospital $(\mathrm{n}=2)$ & 1 & 1 \\
\hline Chughtai's Laboratory $(\mathrm{n}=10)$ & 7 & 3 \\
\hline
\end{tabular}

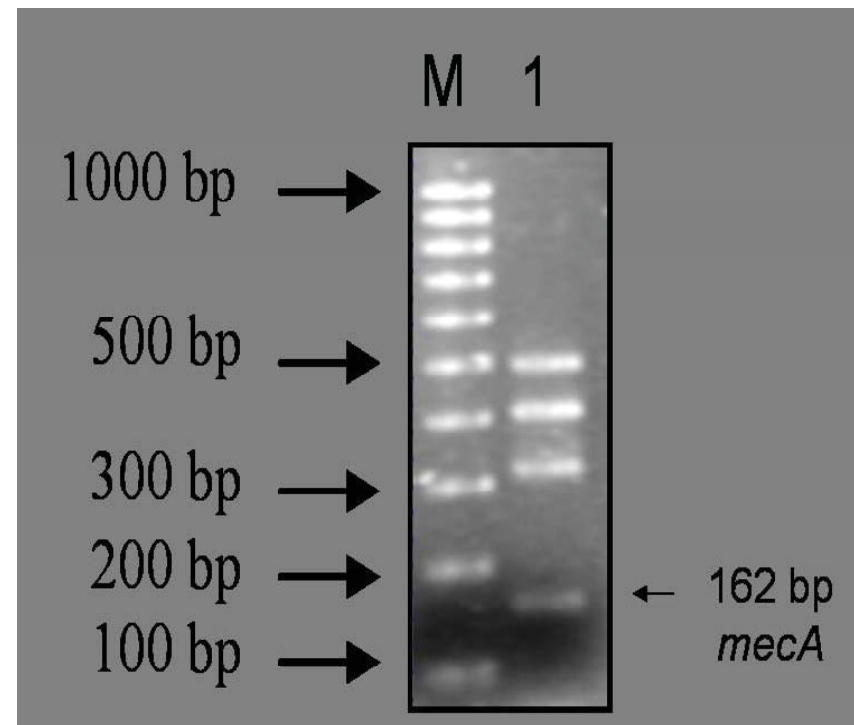

Figure 1. Ethidium bromide stained agarose gel demonstrating PCR amplification of SCCmec type IA DNA fragments. 1: SCCmec type IA pattern (495 bp, $381 \mathrm{bp}$, and 342 bp bands) M: DNA molecular size marker (1-kb DNA ladder; BioRad). mecA gene is indicated by a band of $162 \mathrm{bp}$.

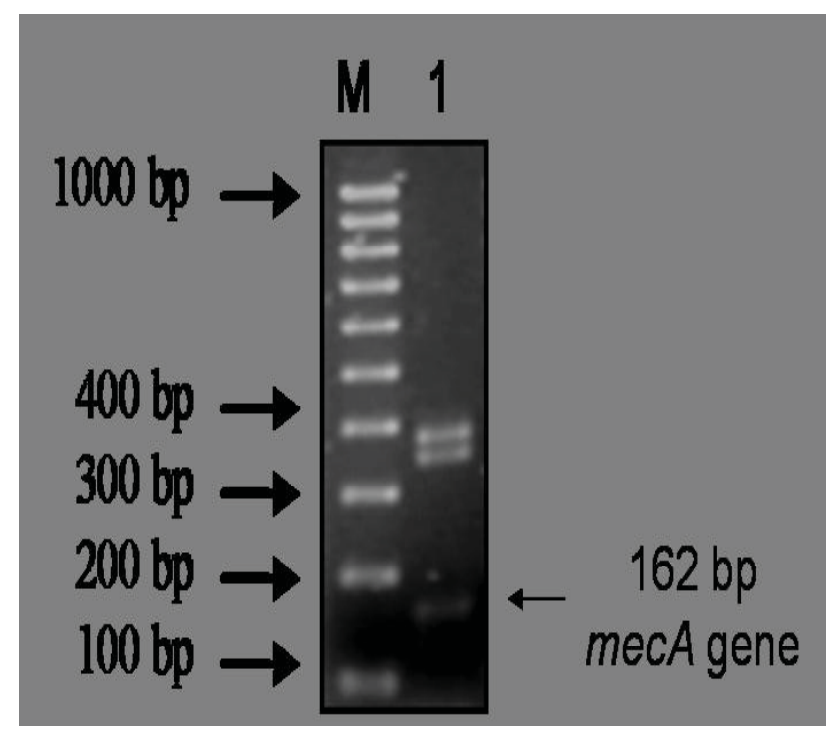

Figure 2. Ethidium bromide stained agarose gel demonstrating PCR amplification of SCCmec type IIC DNA fragments. 1: SCCmec type IIC pattern (381 bp and 342 bp bands) M: DNA molecular size marker (1-kb DNA ladder; BioRad). mecA gene is indicated by a band of 162 bp.

\section{DISCUSSION}

MRSA is the most common antibiotic resistant pathogen present in many regions especially Asia, Europe, America, North Africa and Middle East. ${ }^{2}$ In Asian countries such as Japan, Korea and China the incidence of MRSA has reached higher than 70\%. ${ }^{13}$ Prevalence of MRSA has been reported high in Pakistan, up to $42 \% .{ }^{16,17}$ In many countries including Pakistan the trend of using antibiotics is increasing with the passage of time for various reasons. ${ }^{18}$ Therefore, this inappropriate use of antibiotics favors evolution of resistant pathogens and one of them is MRSA. ${ }^{19}$ Infections caused by these resistant pathogens become difficult to treat incurring prolonged illness, financial burden and higher risk of morbidity and mortality. ${ }^{20}$

Multiplex PCR analysis has revealed that major SC$\mathrm{Cmec}$ types identified in the selected hospitals/laboratories of Lahore are SCCmec type IA and SCCmec type IIC. So far these types have not been reported in other Asian countries including India, China, Japan, Sri Lanka, Taiwan, Korea, Indonesia, Philippines, Singapore, Thailand, Vietnam and Saudi Arabia. ${ }^{13}$ However, SCCmec types found in the present study had been documented and characterized in Europe. SCCmec type I contain mecA and IS1272 for antibiotic resistance and produce two bands of 495 bp and 342 bp and it is resistant to methicillin only. However, its variant $\mathrm{SCCmec}$ type IA contains an integrated plasmid pUB110 downstream of the mec complex, produces an extra band of $381 \mathrm{bp}$. This integrated plasmid pUB110 makes MRSA multiresistant by encoding resistance against kanamycin and tobramycin $(a a d D)$ and bleomycin (ble). IS1272 truncates genes regulating mecA and this result in a de-repression of the mecA gene.

SCCmec type II produces four bands: $381 \mathrm{bp}, 342 \mathrm{bp}$, $284 \mathrm{bp}$ and $209 \mathrm{bp}$. SCCmec type IIC differs from SCCmec type II because it lacks 284 bp band (kdp operon) and the 209 bp amplimer. SCCmec type IIC was first reported in Ireland in 1993. For antibiotic resistance SCCmec type II carries mecA, pUB110 and Tn554. Transposon Tn554 contain ermA gene that encodes resistance against macrolides, lincosamide and spectrograminin. Integrated plasmid pUB110 encodes kanamycin and tobramycin $(a a d D)$ and bleomycin (ble) resistance. ${ }^{1,10,21}$

It is always important to determine the nature of SC$\mathrm{Cmec}$ types prevalent in any region. This information helps in the implementation of strategies to control the transmission of MRSA within the hospitals and in the community as well. 


\section{REFERENCES}

1. Deurenberg RH, Stobberingh EE. The evolution of Staphylococcus aureus. Infect Genet Evol 2008; 8:747-63

2. Grundmann H, Aires de-Sousa M, Boyce J, Tiemersma E. Emergence and resurgence of methicillin-resistant Staphylococcus aureus as public-health threat. Lancet 2006; 368:874-85

3. Feng Y, Chen CJ, Su LH, Hu S, Yu J, Chiu CH. Evolution and pathogenesis of Staphylococcus aureus: lessons learned from genotyping and comparative genomics. Microbiol Rev 2008; 32:23-37

4. Nizet V. Understanding how leading bacterial pathogens subvert innate immunity to reveal novel therapeutic targets. J Allergy Clinical Immunol 2007; 120:13-23

5. Langley R, Wines B, Willoughby N, Basu I, Proft T, Fraser JD. The staphylococcal superantigen-like protein 7 binds IgA and complement C5 and inhibits IgA-FcaR1 binding and serum killing of bacteria. J Immunol 2005; 174:2926-33.

6. Deurenberg RH, Vink C, Kalenic S, Friedrich AW, Bruggeman CA, Stobberingh EE. The molecular evolution of methicillin-resistant Staphylococcus aureus. Clin Microbiol Infect 2007; 13:222-34

7. Katayama Y, Ito T, Hiramatsu K. A new class of genetic element, Staphylococcus cassette chromosome mec, encodes methicillin resistance in Staphylococcus aureus. Antimicrob Agents Chemother 2000; 44:1549-55

8. Lowy FD. Antimicrobial resistance: the example of Staphylococcus aureus. J Clin Invest 2003; 111: 1265-73

9. Hiramatsu K, Katayama Y, Yuzawa H, Ito T. Molecular genetics of methicillin-resistant Staphylococcus aureus. Int J Med Microbiol 2002; 292:67-74

10. Hanssen AN, Sollid JU. SCCmec in staphylococci: genes on move. Immunol Med Microbiol 2006; 46:8-20

11. Ito T, Ma XX, Takeuchi F, Okuma K, Yuzawa H, Hiramatsu K. Novel type V staphylococcal cassette chromosome mec driven by a novel cassette chromosome recombinase, ccrC. Antimicrob Agents Chemother 2004; 48:2637-51

12. Oliveria DC, Milheirico C, Lencastre H. Redefining a structural variant of staphylococcal cassette mec, SCCmec type VI. Antimicrob Agents Chemother 2006; 50:3457-59

13. Ko KS, Le JY, Suh JY, et al. Distribution of major genotypes among methicillin-resistant Staphylococcus aureus clones in Asian countries. J Clin Microbiol 2005; 43:421-26

14. Arakere G, Nadig S, Swedberg G, Macaden R, Amarnath SK, Raghunath D. Genotyping of methicillin-resistant Staphylococcus aureus strains from two hospitals in Bangalore, South India. J Clin Microbiol 2005; 43:3198-202

15. Oliveira DC, Lencastre H. Multiplex PCR strategy for rapid identification of structural types and variants of the mec element in methicillin-resistant Staphylococcus aureus. Antimicrob Agents Chemother 2002; 46:2155-61

16. Siddiquei GM, Kramat AM, Hannan A. Methicillin resistant Staphylococcus aureus: A study of PAF Hospital Sargodha. Pak J Pathology 1999; 10:26-8

17. Ali AM, Abbasi SA, Arif S, and Mirza IA. Nosocomial infections due to methicillin resistant Staphylococcus aureus in hospitalized patients. Pak J Med Sci 2007; 23:593-96

18. Mirza SH. Minimising antibiotic resistance; is there a way forward? Infect Dis J 2007; 75-79

19. Chinedum IE. Microbial resistance to antibiotics. Afr J Biotechnol 2005; 4:1606-11

20. Cosgrove SE, Qi Y, Kaye KS, Harbarth S, Karchmer AW, Carmeli Y. The impact of methicillin resistance in Staphylococcus aureus bacteremia in patient outcomes: mortality, length of stay, and hospital charges. Infect Control Hosp Epidemiol 2005; 26:166-74

21. Shore A, Rossney AS, Keane CT, Enright MC, Coleman DC. Seven novel variants of the staphylococcal chromosomal cassette mec in methicillin-resistant Staphylococcus aureus isolates from Ireland. Antimicrob Agents Chemother 2005; 49:2070-83 